\title{
Feeding choices and impacts of extralimital giraffe on two keystone tree species in the Kgalagadi National Park
}

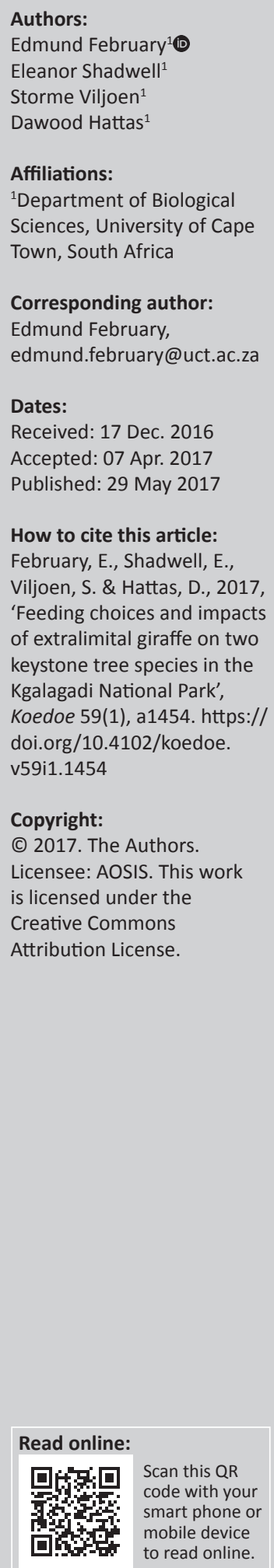

\begin{abstract}
In this article we determine the effect of an extralimital megaherbivore on the reproductive potential and vegetation structure of two keystone tree species in the Auob River in the south western Kalahari Desert of southern Africa. Using spoor and dung counts we establish the presence of giraffe in three predetermined density zones by walking 50 transects across the river in each zone. We also photographed six trees from each species in each zone and use these photographs to determine browse impact on reproductive potential, canopy volume as well as the percentage dieback on the extremities of the canopy. We then perform stable carbon and nitrogen isotope analysis on the leaves of the trees and compare these relative to the isotope ratios of giraffe dung to ascertain dietary preference. Crude protein was determined as a guide to nutritive value. Finally, we determine both chemical and physical defences for the two species. Our results show a significant negative impact of giraffe browse on tree canopies, no significant differences in recruitment and a noticeable decrease in flowers and pods at the giraffe browse height of $2 \mathrm{~m}-5 \mathrm{~m}$. No significant differences in crude protein or condensed tannins were found but significant differences in spinescence. Giraffe are not endemic to the Auob River and our study shows that the introduction of these animals is having a negative impact on the canopies of Vachellia haematoxylon. While there are, as yet, no significant impacts on reproductive potential we speculate that this will happen with time.

Conservation implications: Our study shows that giraffe are significantly impacting the canopies of two common tree species in the Auob River in the arid Kgalagadi Transfrontier Park. Without management intervention an increasing population of giraffe will result in substantial changes to the plant community vegetation structure of the river.
\end{abstract}

\section{Introduction}

For many tourists, the primary reason for visiting an African national park is to see a diversity of large mammals (Grünewald, Schleuning \& Böhning-Gaese 2016). To meet this expectation, giraffe (Giraffe camelopardalis) have been introduced into several reserves in South Africa (Bond \& Loffell 2001; Parker \& Bernard 2005). In 19918 giraffe were introduced into an enclosure near the Craig Lockhart borehole on the Auob River in the Kgalagadi Transfrontier Park in southern Africa, and in 199835 animals were released into the park from this enclosure (Bezuidenhout, Herbst \& Ferreira 2010; Rowland 1991).

While the historic distribution of giraffe probably included the southern Kalahari, there are no historic records for resident populations of these animals in the southern sector of the Kgalagadi Transfrontier Park, where they are considered extralimital (Hall-Martin \& De Graaff 1978; Skinner \& Chimimba 2005). Several studies have demonstrated negative impacts on vegetation structure with extralimital introductions (Bond \& Loffell 2001; Castley, Boshoff \& Kerley 2001; Parker \& Bernard 2005). Giraffe in particular have been shown to exert extreme browse pressure on some Vachellia species to the extent that these may be eliminated from the environment (Bond \& Loffell 2001).

Giraffe are the only exclusively browsing megaherbivore in the Kgalagadi Transfrontier Park, with a distinctive browse range of typically between $2 \mathrm{~m}$ and $5 \mathrm{~m}$, which is higher than all other browsing species such as eland (Taurotragus oryx) and kudu (Tragelaphus strepsiceros) (Owen-Smith 1992). While giraffe may feed on leaves and shoots almost exclusively, flowers, fruits and pods are favoured when available (Owen-Smith 1992). As the food intake of a female giraffe is around 2.1\% of its body mass and $1.6 \%$ for a male, an average $800 \mathrm{~kg}$ female will need approximately $16.8 \mathrm{~kg}$ of browse per day and an average $1200 \mathrm{~kg}$ male $19.2 \mathrm{~kg}$ (Pellew 1984). In 2010 the number of giraffe 
restricted to the Auob River was estimated to be around 50, with between 1 and 55 giraffe sightings per month in 2013 (SANParks [South African National Parks] 2014 unpublished data). From our calculations, 50 giraffe would need around $900 \mathrm{~kg}$ of browse per day in an arid environment where a lack of resources would limit the potential for trees to replace lost biomass (Bloom, Chapin \& Mooney 1985; Chapin 1980).

Large trees in arid savannahs perform essential ecosystem services by providing food, shade, nesting sites and increased nutrients for many other plant and animal species (Dean, Milton \& Jeltsch 1999; Milton \& Dean 1995). Two such species are Vachellia erioloba and Vachellia haematoxylon, both biogeographically endemic to the Kalahari and making up almost all the large trees in the Auob River (Van Rooyen et al. 2008). These two Vachellia species have evolved in this arid environment where the paucity of substrate nutrients result in slow growth rates (Chapin 1980; Dean et al. 1999). As a result, the cost of herbivory is felt more acutely because plants have to draw on finite resources to recuperate biomass losses (Grime 1977).

Here we examine the effects of giraffe browse on the canopies of two important tree species in the Auob River, V. erioloba and $V$. haematoxylon. We do this through an analysis of a series of photographs of trees taken in high, medium and low giraffe density zones. We propose that an increase in browse by giraffe has had a detrimental effect on the plant community vegetation structure of the Auob River by impacting on canopy structure and the reproductive potential of the two tree species through the removal of flowers and seed pods. In this arid environment, trees have slow growth rates, and as a result, we expected increased defences against herbivory (Chapin 1980; Coley, Bryant \& Chapin 1985; Grime 1977). We hypothesise that the tree species with the least defences against herbivory will be most targeted by giraffe, and/or that the most nutritionally valuable species will be favoured as forage. We test this hypothesis through a determination of the relative differences in chemical and physical defences of V. erioloba and V. haematoxylon as well as the nutritional quality of the leaves in the dry season. Finally, we use the stable isotope ratios of giraffe dung to establish the relative contribution of the two tree species to the diet of giraffe in the Auob River (Codron et al. 2007).

By implementing strategic adaptive management, SANParks have integrated science and management (Biggs \& Rogers 2003). For such management to succeed in the Kgalagadi Transfrontier Park, there has to be some understanding of the spatio-temporal heterogeneity of the rivers in the park as these are the centres for biodiversity (Dean et al. 1999). Elucidating the effects that an extralimital megaherbivore may have on this heterogeneity is critical for such an understanding.

\section{Methods}

\section{Study site}

The study site is located along the ephemeral Auob River in the Kgalagadi Transfrontier Park in southern Africa between $-25.79944^{\circ}, 20.0354^{\circ}$ and $-26.4216^{\circ}, 20.6234^{\circ}$. Giraffe were originally introduced into the Auob at the Craig Lockhart borehole $\left(-25.8655^{\circ}, 20.1031^{\circ}\right)$. The results of monthly surveys between February 2012 and March 2014 conducted by SANParks show that the highest densities of giraffe are still in this area decreasing in number down to the confluence with the Nossob River where giraffe are rarely seen (SANParks unpublished data).

The Auob River has a narrow channel between $100 \mathrm{~m}$ and $500 \mathrm{~m}$ wide consisting of fine-grained silts of the Goeboe Goeboe Formation set in $30 \mathrm{~m}$ to $50 \mathrm{~m}$ high banks of calcrete of the Mokalanen Formation (Malherbe 1984; Mills \& Retief 1984). While there is no surface water, the Auob has an aquifer at a depth of between $38 \mathrm{~m}$ and $46 \mathrm{~m}$ below the surface that has been tapped at intervals to supply 15 permanent water holes for animals (Mills \& Retief 1984; Van Wyk \& Le Riche 1984). In this narrow channel, the vegetation is dominated by $V$. erioloba and $V$. haematoxylon as the only tree species and the low shrub Rhigozum trichotomum. Common grasses are Schmidtia kalahariensis, Stipagrostis obtusa and Eragrostis porosa (Van Rooyen et al. 2008).

The annual rainfall for the region is distinctly seasonal occurring as erratic and highly localised thunderstorms between November and April at the hottest time of the year with the coldest season also being the driest. Mean annual rainfall (1984-2014) is $220 \mathrm{~mm}$ at Twee Rivieren $\left(-26.4721^{\circ}\right.$, $20.6116^{\circ}$ ) and mean maximum and minimum temperatures $36.7^{\circ} \mathrm{C}$ and $0.1{ }^{\circ} \mathrm{C}$ (South African Weather Bureau).

\section{Giraffe and tree density}

Based on monthly large-mammal surveys conducted by SANParks between 2012 and 2014, we divided the Auob River downstream of the Mata Mata Rest Camp (-25.7680, $20.0005)$ into three consecutive zones, $\pm 30 \mathrm{~km}$ in length. These zones start as high giraffe density from just below Mata Mata $\left(-25.7944^{\circ}, 20.0354^{\circ}\right.$ to $\left.-25.9636^{\circ}, 20.2446^{\circ}\right)$ through medium-density $\left(-26.9989^{\circ}, 20.3468^{\circ}\right.$ to $\left.-26.1760^{\circ}, 20.5432^{\circ}\right)$ to low-density finishing near the confluence of the Auob and Nossob rivers $\left(-26.1926^{\circ}, 20.5488^{\circ}\right.$ to $\left.-26.4216^{\circ}, 20.6234^{\circ}\right)$.

To confirm our assessment based on the monthly largemammal surveys, we walked 50 transects in each zone perpendicular to the riverbed from mid-slope of one bank to mid-slope of the opposite bank. Each transect was done as a pair, with $150 \mathrm{~m}$ between each transect and $1 \mathrm{~km}$ between each pair of transects. If a borehole (waterhole) were to occur between a pair, a kilometre margin was given on either side to discount the piosphere effect on vegetation and animal density (Chamaillé-Jammes, Fritz \& Madzikanda et al. 2009). In each transect, every occurrence of giraffe spoor and dung was counted by two people $5 \mathrm{~m}$ apart for a total width of $10 \mathrm{~m}$ on each transect.

To determine the effect that giraffe browse may have on tree density, each observer also noted the occurrence of any $V$. erioloba and $V$. haematoxylon in three specific height classes, $0 \mathrm{~m}-0.3 \mathrm{~m}, 0.3 \mathrm{~m}-2 \mathrm{~m}$ and above $2 \mathrm{~m}$. 


\section{Impact of giraffe browse}

To determine the impact of giraffe browse on canopy dieback and reproductive potential (flowers and seed pods), we photographed two trees from each of three height classes $(2 \mathrm{~m}-4 \mathrm{~m}, 4.1 \mathrm{~m}-6 \mathrm{~m}$ and above $6 \mathrm{~m})$ in each giraffe density zone for each species (36 trees). Each tree was photographed twice with each photograph at $90^{\circ}$ to the other. From each photograph, we then determined browse impact for each tree at every metre from $2 \mathrm{~m}$ above ground level to the top of the canopy. We did this from $2 \mathrm{~m}$ above ground level to $5 \mathrm{~m}$ because several studies have shown that while a male giraffe may feed at up to $6 \mathrm{~m}$, the average giraffe browse height for both male and female is between $2 \mathrm{~m}$ and $4.5 \mathrm{~m}$ (Birkett 2002; Du Toit 1990; Young \& Isbell 1991).

All photographs were taken in January 2013 using a Nikon D60 camera (Nikon, Ayuthaya, Thailand) with the entire tree just inside the field of view through an $18 \mathrm{~mm}-200 \mathrm{~mm} \mathrm{f} / 35$ to 6.3-HSM DC lens (Sigma, Fukushima, Japan) fitted with a PRO 1 D UV (W) filter (Kenko, Tokyo, Japan). The aperture was fixed at $52 \mathrm{~mm}, \mathrm{~F} 8$ and a $5 \mathrm{~m}$ retractable aluminium ranging rod (levelling staff; Leica Geosystems, St Gallen, Switzerland) was held vertically at the edge of the canopy for calibration.

The photographs were taken in RAW format and adjusted into TIFF images when analysed in Adobe Photoshop CS5 $\mathrm{v} 12.0 \times 32^{\circ}$ (Adobe Systems Software Ltd, Ireland). Each photograph was overlaid by a calibrated grid $(50 \mathrm{~cm}$ boxes, subdivided by $10 \mathrm{~cm}$; Figure 1-A1). For an assessment of canopy structure, we measured the width of the canopy from edge to edge at every vertical metre starting at $2 \mathrm{~m}$ above ground level. Canopy dieback was determined by marking all living (green leaves) and dead material (brown leaves or twigs or branches $<5 \mathrm{~cm}$ thick) at each grid intercept (11 points) occurring within each of the $50 \mathrm{~cm}$ lengths starting from the outer edge of the canopy moving inwards along the metre-line. We did this for both photographs for each tree. Intercepts occurring in branch or leaf free spaces or with main branches were disregarded. Canopy dieback at each metre-line was calculated as the number of intercepts denoting dead material over the total number of intercepts (living + dead material) and averaged over two photographs. Canopy dieback was also calculated for two sections of each tree, within browse height (2 m$5 \mathrm{~m})$ and above browse height $(>5 \mathrm{~m})$ by averaging the percentage of canopy dieback for each metre-line within each section.

To determine the effects of giraffe browse on reproduction, the numbers of visible flowers and pods were counted in a $50-\mathrm{cm}$ square box; $25 \mathrm{~cm}$ on either side of each horizontal metre-line and $50 \mathrm{~cm}$ inwards from the outer edges of the canopy. The number of boxes depended on how many edges of the canopy there were. We averaged the counts for all the boxes for both photographs of each tree. We do this for each metre-line before averaging all values for above and within browse height for each tree.

\section{Dietary proportion}

We used the stable carbon and nitrogen isotope ratios of leaves and giraffe dung to determine dietary proportion of the two tree species (Codron et al. 2007). For this we collected $\pm 100 \mathrm{~g}$ of fully mature, whole leaves from $2 \mathrm{~m}-5 \mathrm{~m}$ above ground on the northern aspect of 10 trees from each of our two Vachellia species in the high giraffe density zone. Along our transects, we also opportunistically collected 20 fresh giraffe dung samples. Both leaf and dung samples were dried to constant weight at $70{ }^{\circ} \mathrm{C}$ before grinding to a fine powder using a Retsch MM 200 ball mill (Retsch, Haan, Germany). For both leaves and dung, we determined percentage nitrogen as well as isotopic ratios of ${ }^{12} \mathrm{C} /{ }^{13} \mathrm{C}$ and ${ }^{15} \mathrm{~N} /{ }^{14} \mathrm{~N}$ using a Thermo Finnigan Delta plus XP Mass Spectrometer coupled with a Conflo III device to a Thermo Finnigan Flash EA 1112 Elemental Analyser (Thermo Electron Corporation, Milan, Italy). We calibrated the results relative to atmospheric $\mathrm{N}_{2}$ for nitrogen and Pee-Dee Belemnite for carbon as well as to correct for drift in our reference gas. Deviation from the standard is denoted by the term $\delta$, and the results expressed as parts per thousand (\%o). Precision of duplicate analysis is $0.1 \%$ for carbon and $0.2 \%$ for nitrogen (February et al. 2011).

\section{Crude protein}

There is a strong positive correlation between protein content of the leaf and animal preference (Cooper, Owen-Smith \& Bryant 1988; Heady 1964). To assess preference of the foliage of our two tree species to giraffe, we determined differences in crude protein of the leaves by multiplying the foliar percentage nitrogen by 6.25 (Cooper et al. 1988).

\section{Plant defences}

Plants may defend themselves against mammalian herbivory either chemically with high concentrations of condensed tannins and insoluble fibre or structurally with spines or thorns (Hanley et al. 2007; Hattas et al. 2011). Condensed tannins have a characteristic affinity for protein, forming insoluble complexes, which render protein less digestible and thereby reduces forage quality, whereas spines and thorns affect bite size and feeding efficiency (Hattas et al. 2011; Mueller-Harvey 2006). We quantified condensed tannins (proanthocyanidins) while also deriving an index of spinescence for $V$. erioloba and $V$. haematoxylon. Both determinations used the distal $20 \mathrm{~cm}$ of seven branches per tree on which we also counted the number of broken thorns. For this, branches located at $2 \mathrm{~m}-5 \mathrm{~m}$ above ground level were randomly selected from seven trees per species in June 2013. We determined condensed tannins using the acidbutanol assay as described by Hagerman (2002) using Sorghum tannin as a standard (Hattas \& Julkunen-Tiitto 2012). Plant fibre content was determined using the acid detergent fibre (ADF) method in an ANKOM 220 Fiber Analyzer using ADF method 5 (ANKOM Technology).

We counted the number of broken thorns on each branch before measuring thorn length and basal diameter of each thorn, as well as the distance between sets of paired thorns 
(inter-thorn distance) and leaf length, defined as the distance from the petiole intersection on the branch to the tip of the leaf (Midgley, Botha \& Balfour 2001). We used these measurements to develop a spinescence index (T1) to compare the relative degree of physical defence for each species (adapted from Midgley et al. [2001]):

$$
T 1=\frac{\text { thorn length }}{\text { leaf length }} \text { interthorn distance }
$$

\section{Statistical analyses}

Giraffe densities between zones from spoor and dung counts were each tested using a chi-squared test followed by a posthoc paired $t$-test. Differences in the densities of large trees/ha between zone were tested with a Poisson generalised linear model using an offset of log (transect area) to account for any differences in area covered. The densities of juveniles/large tree/ha and intermediates/large tree/ha of each species were both tested with a generalised linear model. Transects with juveniles/intermediates but no large trees were removed from the analyses.

As giraffe browse at heights between $2 \mathrm{~m}$ and $5 \mathrm{~m}$, we compared every metre of canopy width measurement with the 5-m level across different giraffe density zones using a linear mixed-effects model.

Average percentage canopy dieback was arcsine transformed, and all height classes were compared relative to each other and between zones and species using a generalised linear mixed effects model. The same test was used to compare average number of flowers and pods between browse height and above browse height for $V$. haematoxylon ( $V$. erioloba was not flowering) after log transformation of the data. For every analysis, the variance between individual trees was accounted for by including tree number as a random effect. If the interactions between zone and species were not significant, then the analyses were run separately on each species. All tests on the data were assessed in $\mathrm{R}^{\odot} \mathrm{v} 3.1 .2$ (R_Development Core_Team 2014), and a value of $p<0.05$ was required for significance.

We used the SIAR package v4.2 in R v3.1.2 to determine the dietary proportion of each species (Parnell et al. 2010). This package fits a Bayesian Markov chain Monte Carlo (MCMC) model to the dietary habits of giraffe based on the similarity of isotopic ratios between food sources and giraffe dung.
Percentage carbon and nitrogen for each food source (V. erioloba and $V$. haematoxylon) along with the $\delta^{13} \mathrm{C}$ and $\delta^{15} \mathrm{~N}$ values of food sources and dung is incorporated into a linear mixing model.

Calorific content, condensed tannin concentrations, percentages of ADF, carbon and nitrogen, and the proportion of crude protein were compared between the two species using a $T$-test after being tested for normality using a Kolmogorov-Smirnoff test.

Thorn length was averaged for each pair and again for each branch. Leaf length and distance between thorn pairs were averaged for each branch. Significant differences were determined using Mann-Whitney $U$-tests for mean thorn length (only non-zero values included), mean basal diameter and the means for the spinescence index, as these data exhibit a non-parametric distribution according to a Shapiro-Wilk normality test. $T$-tests were used to compare means for leaf length and distance between thorn pairs.

\section{Results \\ Giraffe and tree density}

Our transect results confirmed our assumptions based on the SANParks monthly large-mammal surveys. There was a significant increase in both spoor and dung $(p<0.001$, in both cases) from the low giraffe density zone to the high-density zone. Giraffe spoor and dung were present in, respectively, $28 \%$ and $8 \%$ of transects in the low-density zone, $56 \%$ and $46 \%$ of transects in the medium-density zone and $94 \%$ and $72 \%$ of transects in the high-density zone.

There were significantly more large ( $>2 \mathrm{~m}$ high) $V$. erioloba than large $V$. haematoxylon trees in the Auob River $(p<0.001$, Table 1). There was also a significant increase in the density of large $V$. erioloba from 4.35 trees/ha in the high giraffe density zone to 7.11 trees/ha in the medium-density zone $(p<0.01)$ and a significant decrease to 1.15 trees/ha in the low-density zone. This trend is also reflected non-significantly in the relative proportion of juveniles and intermediates (Table 1).

For $V$. haematoxylon, there are significantly fewer large trees (1.30 trees/ha) in the high giraffe density zone relative to the medium- (3.23 trees/ha) and low-density zones (3.03 trees/ ha, $p<0.001)$. There were however no significant differences in the number of juveniles or intermediates between the different zones (Table 1).

TABLE 1: Relative tree densities in three specific height classes: juvenile, intermediate and large ( $0 \mathrm{~m}-0.3 \mathrm{~m}, 0.3 \mathrm{~m}-2 \mathrm{~m}$, and above $2 \mathrm{~m}$, respectively) in each of the three giraffe density zones, low, medium and high.

\begin{tabular}{|c|c|c|c|c|}
\hline Species & Density zone & Juveniles/large tree/ha (Mean $\pm \mathrm{SE}$ ) & Intermediates/large tree/ha (Mean \pm SE) & Large tree/ha (Mean $\pm \mathrm{SE}$ ) \\
\hline \multirow[t]{3}{*}{ Vachellia erioloba } & Low & $3.79 \pm 1.63$ & $3.28 \pm 2.28$ & $1.15 \pm 0.16$ \\
\hline & Medium & $7.57 \pm 1.86$ & $5.00 \pm 1.11$ & $7.11 \pm 1.01$ \\
\hline & High & $6.73 \pm 3.13$ & $5.61 \pm 1.99$ & $4.35 \pm 0.62$ \\
\hline \multirow[t]{3}{*}{ Vachellia haematoxylon } & Low & $0.18 \pm 0.18$ & $4.31 \pm 1.86$ & $3.03 \pm 0.43$ \\
\hline & Medium & $0.28 \pm 0.29$ & $2.25 \pm 0.83$ & $3.23 \pm 0.46$ \\
\hline & High & $0.42 \pm 0.42$ & $3.50 \pm 0.91$ & $1.30 \pm 0.18$ \\
\hline
\end{tabular}

Values are means \pm 1 standard error.

$\mathrm{SE}$, standard error. 


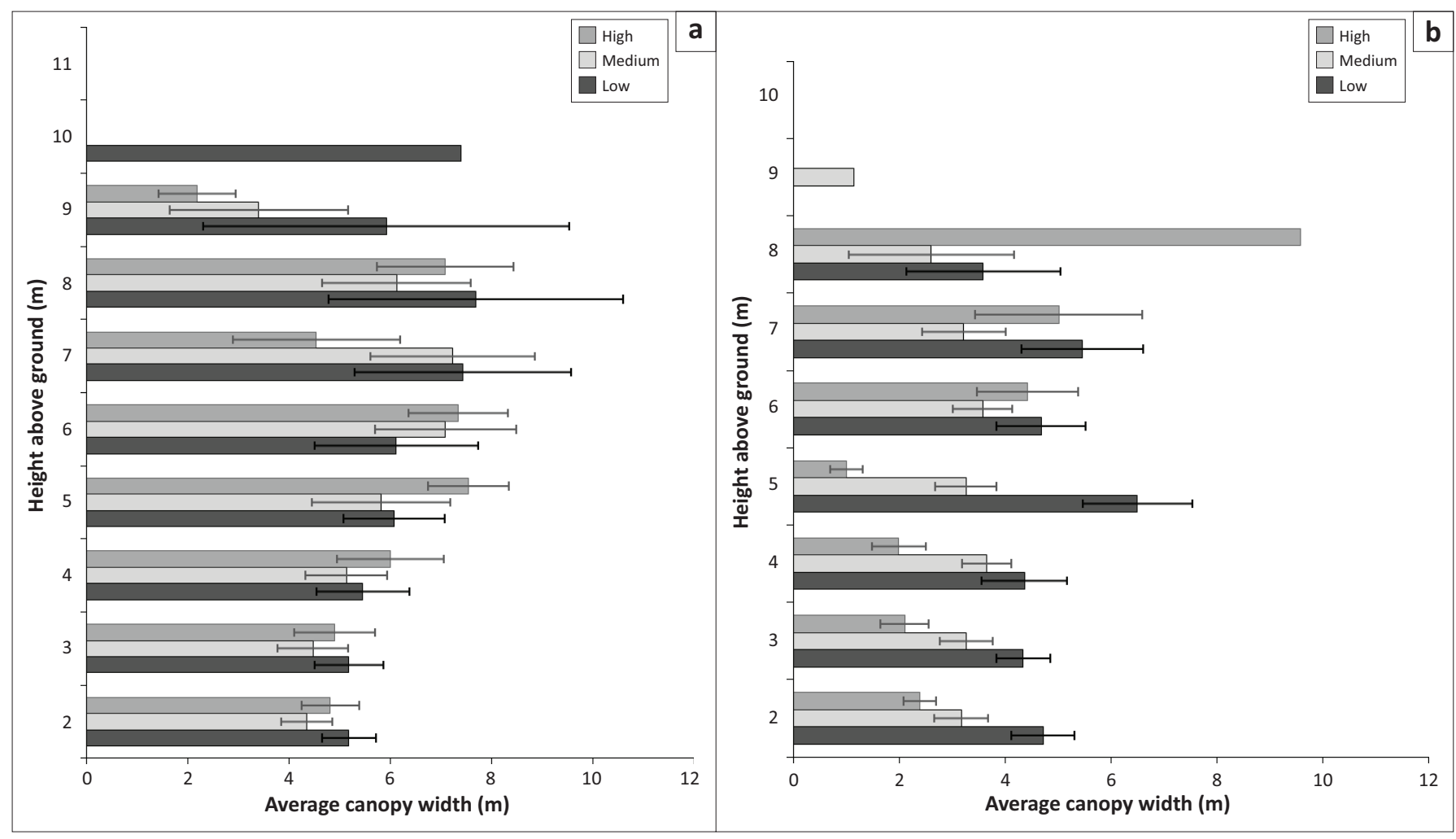

Values are means \pm 1 standard error.

FIGURE 1: Average canopy width for (a) Vachellia erioloba and (b) Vachellia haematoxylon in the low, medium and high giraffe density zones.

\section{Impact of giraffe browse}

There were no significant effects of giraffe browse on canopy width for $V$. erioloba between the different zones. There were also no significant differences in canopy width for $V$. haematoxylon between the medium- and high-density zones, but there were significant differences in canopy width between the high/medium-density zones and the lowdensity zone $(p<0.05)$. Across all density zones $V$. haematoxylon canopies were significantly narrower below $5 \mathrm{~m}$ relative to the 5 - $\mathrm{m}$ browse height (Figure 1, $p<0.05$ ).

Our results show high levels of canopy dieback in $V$. haematoxylon relative to $V$. erioloba in all giraffe density zones $(p<0.001)$ with average percentage dieback for V. haematoxylon twice that of $V$. erioloba (Figure 2). In the high-density zone, there was more canopy dieback for $V$. erioloba between $2 \mathrm{~m}$ and $5 \mathrm{~m}$ than in the other two zones increasing from $6.5 \%$ in the low-density zone through $12 \%$ in the medium-density zone to $15.3 \%$ in the high-density zone. For V. haematoxylon, there was an increase in canopy dieback as giraffe density increases with the greatest percentage dieback in the highdensity zone between $2 \mathrm{~m}$ and $4 \mathrm{~m}(p<0.05$, Figure 2$)$.

For $V$. haematoxylon, there were significantly more flowers per tree in the low-density zone $(2.03 \pm 0.93$ mean \pm standard error [SE] $)$ than in the medium-density $(0.17 \pm 0.11$ mean \pm $\mathrm{SE})$ and no flowers in the high giraffe density zone $(p<0.05)$. There were however no significant differences in the number of flowers in the browse range $(2 \mathrm{~m}-5 \mathrm{~m})$ and above browse range. There were also no significant differences in the number of pods above and below giraffe browse height for either species (Figure 2-A1).

\section{Stable isotope ratios}

There was no significant difference in $\delta^{13} \mathrm{C}$ values between $V$. erioloba $(-26.3 \%$ o ) and $V$. haematoxylon $(-25.7 \%$ ). There was however a significant difference in $\delta^{15} \mathrm{~N}$ values $(p<0.01)$, which allows these two Vachellia species to be differentiated isotopically. Giraffe dung $\delta^{15} \mathrm{~N}$ values (5.5\%o) were more similar to $V$. haematoxylon $(6.1 \%$ ) than $V$. erioloba $(8.4 \%$ ). The results from our model show that up to $100 \%$ of the diet of giraffe is $V$. haematoxylon $(79 \%, \pm 20.5 \%$, mean \pm SE) with only a small proportion of $V$. erioloba $(21 \%, \pm 20.5 \%$, mean \pm SE, Figure 3).

\section{Crude protein}

There was a significantly higher concentration of crude protein $(p<0.05)$ and lower C:N ratio $(p<0.01)$ in V. erioloba $(13.8 \%$ and $22.1 \%)$ than in $V$. haematoxylon $(12.2 \%$ and $25.8 \%$ ).

\section{Plant defences}

There were no significant differences between the two tree species in condensed tannin concentrations (V. erioloba $3.3 \% \pm$ 0.32 and $V$. haematoxylon $2.9 \% \pm 0.29$, mean \pm SE) but there are significant $(p<0.001)$ differences in thorn length and thorn basal diameter, with $V$. erioloba having longer $(21.6 \mathrm{~mm} \pm 11.9 \mathrm{~mm}$ and $19.0 \mathrm{~mm} \pm 11.8 \mathrm{~mm})$ and thicker $(2.5 \mathrm{~mm} \pm 1.4 \mathrm{~mm}$ and $0.7 \mathrm{~mm}$ $\pm 0.3 \mathrm{~mm}$ ) thorns than $V$. haematoxylon. Percentage ADF in $V$. haematoxylon was significantly higher $(11.3 \%)$ than that of V. erioloba $(50.1 \pm 0.81 \%$ and $44.4 \pm 0.61 \%$, mean $\pm \mathrm{SE}, p<0.0001)$. Of the two trees, $V$. haematoxylon also had a significantly 




Values are means \pm 1 standard error.

FIGURE 2: Average canopy dieback for (a) Vachellia erioloba and (b) Vachellia haematoxylon in each of the giraffe density zones.

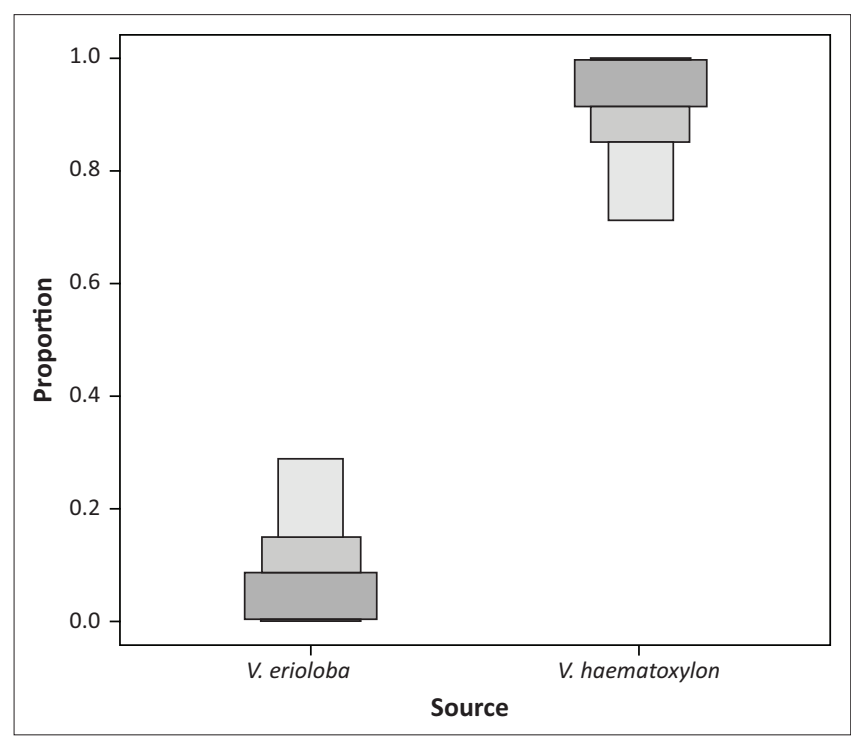

Increasing shades of grey from light to dark are the $95 \%, 75 \%$ and $25 \%$ credibility interval of the estimates.

FIGURE 3: The relative proportion of Vachellia erioloba and Vachellia haematoxylon in the diet of giraffe in the Auob River as derived from stable isotope analysis of dung.

$(p<0.001)$ greater proportion of broken thorns per branch $(22.4 \pm 13.2$ and $11.8 \pm 13.8$, mean \pm SE). The results for our spinescence index shows that $V$. erioloba is significantly better physically defended than $V$. haematoxylon (Figure $4, p<0.05$ ).

\section{Discussion}

Giraffe densities are highest in the zone closest to the point of release near the Craig Lockhart borehole on the Auob River decreasing downstream towards the confluence with the

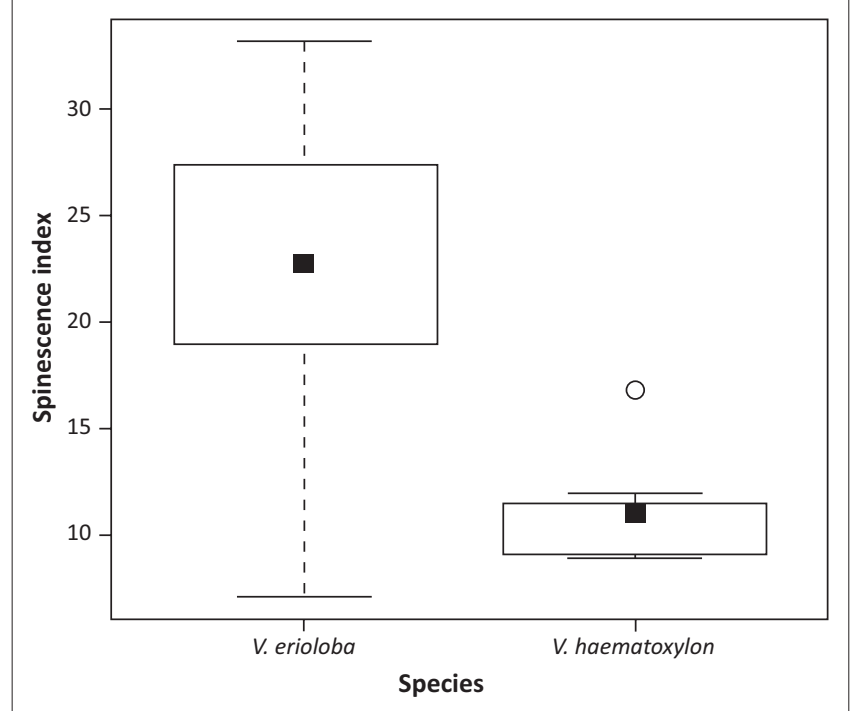

$U=7.00, p<0.05$.

FIGURE 4: Means and interquartile range for our spinescence indices showing that Vachellia erioloba is significantly more spinescent that Vachellia haematoxylon.

Nossob. This distribution coincides with the densities of large trees with $V$. erioloba highest and $V$. haematoxylon lowest where the densities of giraffes are highest. The density of large $V$. haematoxylon trees increases from the high giraffe density zone to the low-density zone. This increase is coincidental with our results for browse impact, which shows that while the highest impact of giraffe browse is in the highdensity zone, this impact is not on $V$. erioloba but rather on $V$. haematoxylon. When compared relative to trees in the medium- and low-density zones, there was no significant 
change in canopy structure for V. erioloba but much narrower canopies and significantly higher canopy dieback on $V$. haematoxylon in the high-density zone. While the canopy dieback reported here may be attributed to drought or natural mortality, these results are closely correlated with giraffe density and it is therefore most likely that giraffe are the cause. Short periods of drought should also not result in canopy dieback because these trees are sourcing water from a deep aquifer and are therefore not reliant on immediate rainfall (Schachtschneider \& February 2013; Shadwell \& February 2017).

Vachellia erioloba flowers between July and September and $V$. haematoxylon between November and January (Coates Palgrave 2002; Sekhwela \& Yates 2007). As our photographs were taken in January, which is a month after the flowering period for $V$. erioloba and at the end of flowering for $V$. haematoxylon, it is not surprising that we saw no flowers on $V$. erioloba trees. Our results showing no flowers on $V$. haematoxylon in the high giraffe density zone and significantly fewer flowers in the medium zone relative to the low-density zone may also be the result of a combination of both flowering phenology and giraffe browse. More research has to be done on this to determine the exact effect of giraffe browse on the amount of flowers.

The pods of both $V$. erioloba and $V$. haematoxylon are indehiscent and sought after by mammals, with passage through the gut aiding germination (Leistner 1961). Vachellia erioloba sets seed from December to March and $V$. haematoxylon from January to April (Coates Palgrave 2002; Sekhwela \& Yates 2007). The very few pods on $V$. haematoxylon relative to $V$. erioloba across all giraffe density zones in our study may therefore relate to seed set rather than giraffe browse (Coates Palgrave 2002; Sekhwela \& Yates 2007). Research has however shown a distinct browse line for pods on $V$. erioloba resulting from giraffe browse (Coe 1998). As seed pods that fall to the ground are readily infected by bruchid beetle, germination success is higher for ingested seed taken from the tree (Hoffman et al. 1989). Giraffe browse of the seed pod may therefore aid rather than retard germination for our two study species.

Our transect results show no correlation between the number of juvenile $V$. haematoxylon trees and giraffe density. The reason for this could be that savannah trees have a high resilience to stem mortality and may persist as juveniles for many decades (Higgins et al. 2007). The drivers for Vachellia seed germination and establishment at our study site are not clear but once established those trees top killed by fire, herbivory or drought can persist for many decades resprouting from the base using stored resources (Schutz, Bond \& Cramer 2011).

The increased impact of giraffe on the canopy of $V$. haematoxylon rather than $V$. erioloba as demonstrated by our photographic analysis is corroborated by our stable isotope analysis that shows $80 \%$ of giraffe diet to be V. haematoxylon.
There were no significant differences in the concentration of condensed tannins between the two species demonstrating that neither species were better chemically defended (Cooper \& Owen-Smith 1985). These concentrations, for both species, were less than the frequently reported 5\% threshold above which condensed tannins are purported to negatively affect diet selection (Cooper \& Owen-Smith 1985). Calorific content also did not differ between the two species, but there was a significant difference in C:N ratios making $V$. erioloba with lower C:N ratios more preferable as a food source (PérezHarguindeguy et al. 2003).

Our spinescence index showed that V. erioloba with thicker, longer and denser thorns was considerably better physically defended against herbivory than $V$. haematoxylon. On several occasions, we witnessed giraffe with their heads inside the canopy of a $V$. haematoxylon, which is likely what caused the greater degree of broken thorns on $V$. haematoxylon branches in our study. Several studies have noted that giraffe are impervious to physical defences by thorns (Cooper \& OwenSmith 1986; Pellew 1984), however the results of our study would suggest that the longer, thicker, more prolific thorns on $V$. erioloba may explain why giraffe have a dietary preference for $V$. haematoxylon even though $V$. erioloba is more nutritious.

\section{Conclusion}

Our study is equivocal in demonstrating a relationship between giraffe and seedling establishment at our study site. It does however show that giraffe are significantly reducing the canopies of both common tree species in the Auob River. This impact is far greater for $V$. haematoxylon than for $V$. erioloba and if allowed to continue could lead to substantial changes in the plant community vegetation structure of the Auob River. It has been proposed that large trees in arid savannahs perform essential ecosystem services by providing food, shade, nesting sites and increased nutrients for many other plant and animal species (Dean et al. 1999; Milton \& Dean 1995). Any decline of these large trees will have considerable implications for biodiversity conservation. Giraffe are regarded as an extralimital in the Kgalagadi Transfrontier Park and were primarily introduced to promote tourism (Hall-Martin \& De Graaff 1978; Rowland 1991; Skinner \& Chimimba 2005). While the economic benefits of tourism are important for socio-economic development, management has to consider the implications of an increasing giraffe population on biodiversity conservation. Our study is the first step in implementing strategic adaptive management that will allow for a compromise between increased tourism revenue and biodiversity conservation (Biggs \& Rogers 2003). Such adaptive management could consider future research on why giraffe have not moved away from the area of highest impact into the medium and low-density zones where the densities of large $V$. haematoxylon are higher. Future research could also focus on the effect of giraffe on seedling establishment of our two study species. 


\section{Acknowledgements}

The authors thank SANParks for allowing them to do the research in the Kgalagadi Transfrontier Park. The authors are grateful to Graeme Ellis, Paola Vimercati, Chantal Elston and Amy Betzelberger for their help with the fieldwork. The data are available at the South African National Park Data Repository http:/ /dataknp.sanparks.org/sanparks/metacat/ judithk.111224.3/sanparks. Funding for the project was through a grant from the Mellon Foundation of New York.

\section{Competing interests}

The authors declare that they have no financial or personal relationships that may have inappropriately influenced them in writing this article.

\section{Authors' contributions}

E.F. originated the study. E.F., E.S. and S.V. designed the experiments and conducted the field work. E.S. and S.V. performed the statistical analysis. S.V. conducted the dietary proportion, and D.H. and S.V. did the plant defences analysis. E.S. conducted the impact of giraffe browse and giraffe density analysis. E.F., E.S. and S.V. wrote the first draft, and all authors contributed equally to the final draft.

\section{References}

Bezuidenhout, H., Herbst, M. \& Ferreira, S., 2010, An assessment of the proposed giraffe translocation from the Mata Mata section to Unions End in the Kalahar Gemsbok National Park, SANParks Internal Report, South African National Parks, Kimberley, South Africa.

Biggs, H.C. \& Rogers, K.H., 2003, 'An adaptive system to link science, monitoring and management in practice', in H.C. Biggs, K.H. Rogers \& J. Du Toit (eds.), The Kruger experience. Ecology and management of savanna heterogeneity, pp. 59-80, Island Press, Washington, DC.

Birkett, A., 2002, 'The impact of giraffe, rhino and elephant on the habitat of a black rhino sanctuary in Kenya', African Journal of Ecology 40, 276-282. https://doi. org/10.1046/j.1365-2028.2002.00373.x

Bloom, A.J., Chapin, F.S. \& Mooney, H.A., 1985, 'Resource limitation in plants - An economic analogy', Annual Review of Ecology and Systematics 16, 363-392. https://doi.org/10.1146/annurev.es.16.110185.002051

Bond, W.J. \& Loffell, D., 2001, 'Introduction of giraffe changes Acacia distribution in a South African savanna', African Journal of Ecology 39, 286-294. https://doi. org/10.1046/j.1365-2028.2001.00319.x

Castley, J., Boshoff, A. \& Kerley, G., 2001, 'Compromising South Africa's natural biodiversity: Inappropriate herbivore introductions', South African Journal of Science 96, 365-378.

Chamaillé-Jammes, S., Fritz, H. \& Madzikanda, H., 2009, 'Piosphere contribution to landscape heterogeneity: A case study of remote-sensed woody cover in a high elephant density landscape', Ecography 32, 871-880. https://doi.org/10.1111/j. 1600-0587.2009.05785.x

Chapin, F.S., 1980, 'The mineral nutrition of wild plants', Annual Review of Ecology and Systematics 11(1), 233-260. https://doi.org/10.1146/annurev.es.11.110180. 001313

Coates Palgrave, K., 2002, Trees of southern Africa, Struik, Cape Town.

Codron, D., Codron, J., Lee-Thorp, J., Sponheimer, M., De Ruiter, D., Sealy, J. et al., 2007 'Diets of savanna ungulates from stable carbon isotope composition of faeces', Journal of Zoology 273, 21-29. https://doi.org/10.1111/j.1469-7998.2007.00292.x

Coe, M., 1998, 'Some aspects of the interaction between mammalian herbivores and Acacia eriobola E. Mey', Transactions of the Royal Society of South Africa 53, 141-147. https://doi.org/10.1080/00359199809520382

Coley, P.D., Bryant, J.P. \& Chapin, F.S., 1985, 'Resource availability and plant antiherbivore defense', Science 230, 895-899.

Cooper, S.M. \& Owen-Smith, N., 1985, 'Condensed tannins deter feeding by browsing ruminants in a South African savanna', Oecologia 67, 142-146. https://doi. org/10.1007/BF00378466

Cooper, S.M. \& Owen-Smith, N., 1986, 'Effects of plant spinescence on large mammalian herbivores', Oecologia 68, 446-455. https://doi.org/10.1007/BF00376934
Cooper, S.M., Owen-Smith, N. \& Bryant, J.P., 1988, 'Foliage acceptability to browsing ruminants in relation to seasonal changes in the leaf chemistry of woody plants in a ruminants in relation to seasonal changes in the leaf chemistry of woody plants in a
South African savanna', Oecologia 75, 336-342. https://doi.org/10.1007/BF01036753

Dean, W., Milton, S. \& Jeltsch, F., 1999, 'Large trees, fertile islands, and birds in arid savanna', Journal of Arid Environments 41, 61-78. https://doi.org/10.1006/ jare.1998.0455

Du Toit, J., 1990, 'Feeding-height stratification among African browsing ruminants', African Journal of Ecology 28, 55-61. https://doi.org/10.1111/j.1365-2028.1990. tb01136.x

February, E.C., Allsopp, N., Shabane, T. \& Hattas, D., 2011, 'Coexistence of a C 4 grass and a leaf succulent shrub in an arid ecosystem. The relationship between rooting depth, water and nitrogen', Plant and Soil 349(1-2), 253-260. https://doi. org/10.1007/s11104-011-0867-y

Grime, J.P., 1977, 'Evidence for the existence of three primary strategies in plants and its relevance to ecological and evolutionary theory', American Naturalist 111(982), 1169-1194. https://doi.org/10.1086/283244

Grünewald, C., Schleuning, M. \& Böhning-Gaese, K., 2016, 'Biodiversity, scenery and infrastructure: Factors driving wildlife tourism in an African savannah national park', Biological Conservation 201, 60-68. https://doi.org/10.1016/j.biocon. 2016.05.036

Hagerman, A.E., 2002, The Tannin handbook (updated: 2011), Department of Chemistry \& Biochemistry, Miami University, Coral Gables, FL.

Hall-Martin, A., \& De Graaff, G., 1978, 'A note on the feasibility of introducing giraffe to the Kalahari Gemsbok National Park', Koedoe 21, 191-193. https://doi. org/10.4102/koedoe.v21i1.973

Hanley, M.E., Lamont, B.B., Fairbanks, M.M. \& Rafferty, C.M., 2007, 'Plant structural traits and their role in anti-herbivore defence', Perspectives in Plant Ecology, Evolution and Systematics 8, 157-178. https://doi.org/10.1016/j.ppees. 2007.01.001

Hattas, D., Hjältén, J., Julkunen-Tiitto, R., Scogings, P.F. \& Rooke, T., 2011, 'Differential phenolic profiles in six African savanna woody species in relation to antiherbivore defense', Phytochemistry 72, 1796-1803. https://doi.org/10.1016/j.phytochem. 2011.05.007

Hattas, D. \& Julkunen-Tiitto, R., 2012, 'The quantification of condensed tannins in African savanna tree species', Phytochemistry Letters 5, 329-334. https://doi. org/10.1016/j.phytol.2012.02.013

Heady, H.F., 1964, 'Palatability of herbage and animal preference', Journal of Range Management 17, 76-82. https://doi.org/10.2307/3895315

Higgins, S.I., Bond, W.J., February, E.C., Bronn, A., Euston-Brown, D.I.W., Enslin, B. et al., 2007, 'Effects of four decades of fire manipulation on woody vegetation structure in savanna', Ecology 88, 1119-1125. https://doi.org/10.1890/06-1664

Hoffman, M., Cowling, R., Douie, C. \& Pierce, S., 1989, 'Seed predation and germination of Acacia erioloba in the Kuiseb River Valley, Namib Desert', South African Journa of Botany 55, 103-106. https://doi.org/10.1016/S0254-6299(16)31237-6

Leistner, O., 1961, 'On the dispersal of Acacia giraffae by game', Koedoe 4, 101-104. https://doi.org/10.4102/koedoe.v4i1.831

Malherbe, S., 1984, 'The geology of the Kalahari Gemsbok National Park', Koedoe 27, 33-44. https://doi.org/10.4102/koedoe.v27i2.567

Midgley, J., Botha, M. \& Balfour, D., 2001, 'Patterns of thorn length, density, type and colour in African Acacias', African Journal of Range and Forage Science 18, 59-61. https://doi.org/10.2989/10220110109485756

Mills, M. \& Retief, P., 1984, 'The response of ungulates to rainfall along the riverbeds of the southern Kalahari', Koedoe 27, 129-141. https://doi.org/10.4102/koedoe. v27i2.574

Milton, S. \& Dean, W., 1995, 'How useful is the keystone species concept, and can it be applied to Acacia erioloba in the Kalahari Desert?', Zeitschrift fuer Oekologie und Naturschutz 3, 147-156.

Mueller-Harvey, I., 2006, 'Unravelling the conundrum of tannins in animal nutrition and health', Journal of the Science of Food and Agriculture 86, 2010-2037. https:// doi.org/10.1002/jsfa.2577

Owen-Smith, R.N., 1992, Megaherbivores: The influence of very large body size on ecology, Cambridge University Press, New York.

Parker, D. \& Bernard, R., 2005, 'The diet and ecological role of giraffe (Giraffa camelopardalis) introduced to the Eastern Cape, South Africa', Journal of Zoology 267, 203-210. https://doi.org/10.1017/S0952836905007399

Parnell, A.C., Inger, R., Bearhop, S. \& Jackson, A.L., 2010, 'Source partitioning using stable isotopes: Coping with too much variation', PLoS One 5, e9672. https://doi. org/10.1371/journal.pone.0009672

Pellew, R.A., 1984, 'Food consumption and energy budgets of the giraffe', Journal of Applied Ecology 21(1), 141-159. https://doi.org/10.2307/2403043

Pérez-Harguindeguy, N., Díaz, S., Vendramini, F., Cornelissen, J.H., Gurvich, D.E. \& Cabido, M., 2003, 'Leaf traits and herbivore selection in the field and in cafeteria experiments', Austral Ecology 28, 642-650. https://doi.org/10.1046/j.1442-9993. 2003.01321.x

R Development_Core_Team., 2014, R: A language and environment for statistical computing, $\overline{\mathrm{R}}$ Foundation for Statistical Computing, Vienna, Austria.

Rowland, F., 1991, Kameelperde pas goed aan in Kalahari, pp. 31-35, Custos, South African National Parks, Pretoria.

Schachtschneider, K. \& February, E.C., 2013, 'Impact of Prosopis invasion on a keystone tree species in the Kalahari Desert', Plant Ecology 214, 597-605. https:// doi.org/10.1007/s11258-013-0192-z 
Schutz, A.E., Bond, W.J. \& Cramer, M.D., 2011, 'Defoliation depletes the carbohydrate reserves of resprouting Acacia saplings in an African savanna', Plant Ecology 212 2047-2055. https://doi.org/10.1007/s11258-010-9883-x

Sekhwela, M. \& Yates, D., 2007, 'A phenological study of dominant Acacia tree species in areas with different rainfall regimes in the Kalahari of Botswana', Journal of Arid Environments 70, 1-17. https://doi.org/10.1016/j.jaridenv. 2006.12.006

Shadwell, E. \& February, E., 2017, 'Effects of groundwater abstraction on two keystone tree species in an arid savanna national park', PeerJ 5, e2923. https://doi. org/10.7717/peerj.2923
Skinner, J.D. \& Chimimba, C.T., 2005, The mammals of the southern African sub-region, Cambridge University Press, Cape Town.

Van Rooyen, M.W., Van Rooyen, N., Bothma, J.d.P. \& Van den Berg, H.M, 2008, 'Landscapes in the Kalahari Gemsbok National Park, South Africa', Koedoe 50 99-112. https://doi.org/10.4102/koedoe.v50i1.154

Van Wyk, P., \& Le Riche, E., 1984, 'The Kalahari Gemsbok National Park: 1931-1981', Koedoe 27, 21-31. https://doi.org/10.4102/koedoe.v27i2.566

Young, T.P. \& Isbell, L.A., 1991, 'Sex differences in giraffe feeding ecology: Energetic and social constraints', Ethology 87, 79-89. https://doi.org/10.1111/j.1439-0310. 


\section{Appendix 1}

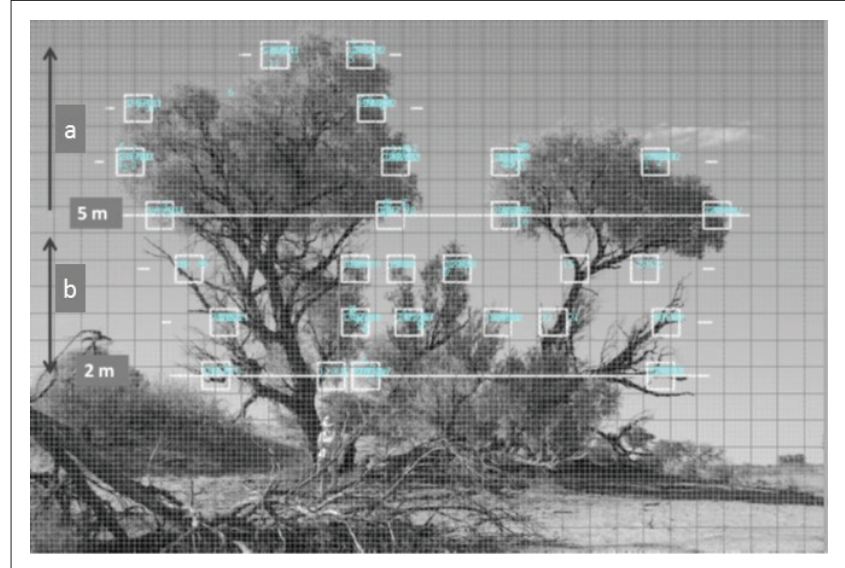

Source: Photograph taken by Eleanor Shadwell

$\mathrm{a}=2 \mathrm{~m}-5 \mathrm{~m} ; \mathrm{b}=\geq 5 \mathrm{~m}$.

FIGURE 1-A1: An illustration of the grid overlay and intercept counting method used for determining the amount of live or dead canopy material and the number of flowers and pods in the browse range and above browse range.
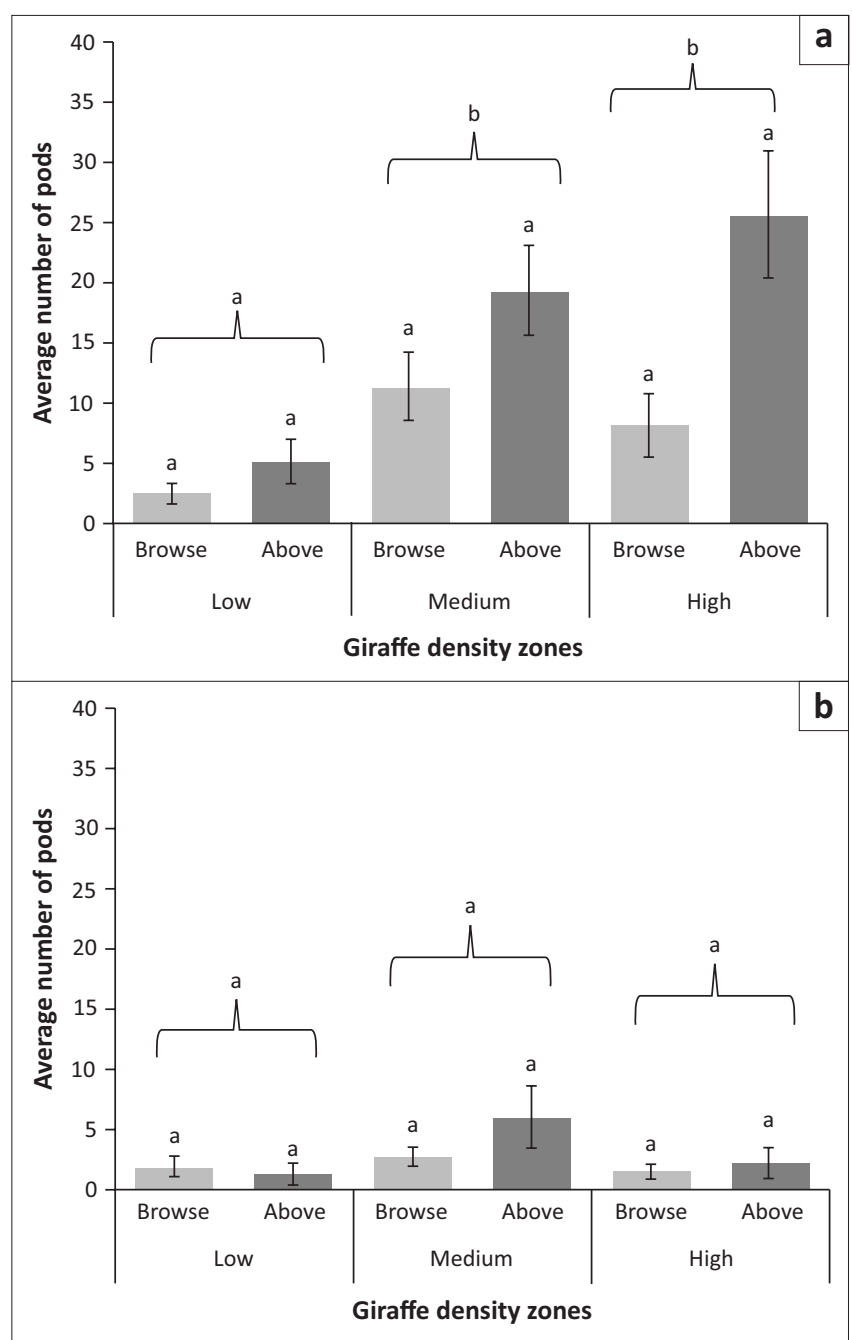

FIGURE 2-A1: Average number of pods ( \pm standard error) for (a) Vachellia erioloba and (b) Vachellia haematoxylon in each of the giraffe density zones (low, medium and high). 